\title{
Persepsi Masyarakat terhadap Dampak Limbah Tahu di Sekitar Sungai
}

\author{
${ }^{1}$ Nina Shaskia, ${ }^{2}$ Irda Yunita \\ ${ }^{1}$ Program Studi Teknik Sipil, Fakultas Teknik, Universitas Syiah Kuala \\ ${ }^{2}$ Program Studi Teknik Lingkungan, Fakultas Teknik, Universitas Serambi Mekkah \\ 1ninashaskia@unsyiah.ac.id, 2irda.yunita@serambimekkah.ac.id
}

\begin{abstract}
The tofu processing sector is quickly expanding in tandem with the popularity of tofu meals among Indonesians. Unfortunately, the tofu industri's rapid growth has not been matched by effective waste management, and as a result, many businesses continue to dump liquid waste directly into rivers without treatment. In the Krueng Daroy and Krueng Doy River sections of Banda Aceh, there are three tofu factories that directly dump liquid waste into the river and have the potential to damage the river. As a result, the goal of this study is to examine the public's perception of tofu waste's influence on the river ecosystem and to assess public comprehension of tofu waste's impact on the environment. The descriptive analysis method was used in this study. Questionnaires, observations, and interviews were used to gather information. After that, the data was descriptively processed and weighted. The findings are divided into three categories: public perception of aesthetics, public perception of smell, and public perception of the environmental impact of tofu waste. More than $90 \%$ of the respondents thought that tofu waste had a negative impact on the environment's aesthetics and produced stink. The public's impression of tofu waste in the river environment is 78.56 percent, which means that more than 75 percent of respondents believe tofu waste has an environmental impact. It is included in the "disturbing" category based on the average attitude rating of 785.6. This demonstrates that tofu waste has a detrimental environmental impact. As a result, business actors must get a better understanding of the impact of tofu waste on the environment, as well as the efforts that must be done to reduce that impact, such as constructing an appropriate Waste Treatment Plant (IPAL) or repurposing tofu liquid waste for other purposes.
\end{abstract}

Keywords: Public Perception, Tofu Waste, Tofu, Waste, River.

\begin{abstract}
Abstrak
Seiring dengan populernya makanan tahu di kalangan masyarakat Indonesia, industri pengolahan tahu semakin berkembang pesat. Sayangnya, pesatnya pertumbuhan industri tahu ini tidak diimbangi dengan pengelolaan limbah yang memadai, akibatnya masih banyak pelaku usaha yang membuang limbah langsung ke sungai tanpa pengolahan. Di Banda Aceh, terdapat 3 pabrik tahu di kawasan Sungai Krueng Daroy dan Krueng Doy yang langsung membuang limbah ke sungai dan berpotensi mencemari sungai. Oleh karena itu, penelitian ini bertujuan untuk mengetahui persepsi masyarakat terhadap dampak limbah tahu di lingkungan sungai serta mengevaluasi pemahaman masyarakat dalam hal dampak limbah tahu terhadap lingkungan. Penelitian ini dilakukan dengan menggunakan metode kualitatif. Data-data diperoleh melalui kuesioner, observasi serta wawancara. Data yang diperoleh kemudian diolah secara deskriptif dan pembobotan. Hasil penelitian disajikan dalam tiga kategori, yaitu persepsi masyarakat terhadap estetika, persepsi masyarakat terhadap bau, dan persepsi masyarakat terhadap dampak limbah tahu pada lingkungan. Hasil penelitian menunjukkan lebih dari $90 \%$ responden setuju bahwa limbah tahu memiliki dampak negatif terhadap estetika lingkungan dan menimbulkan bau yang sangat mengganggu. Tingkat persepsi masyarakat terhadap limbah tahu pada lingkungan sungai diperoleh $78,56 \%$, artinya lebih dari $75 \%$ responden setuju bahwa limbah tahu memiliki dampak terhadap lingkungan. Dilihat dari rata-rata nilai sikap yaitu sebesar 785,6 termasuk dalam kriteria "mengganggu". Hal ini menunjukkan bahwa limbah tahu memiliki dampak negatif terhadap lingkungan. Oleh karena itu, perlu adanya peningkatan pemahaman pelaku usaha akan dampak limbah tahu terhadap lingkungan beserta langkah-langkah yang harus dilakukan untuk meminimalisasi dampaknya terhadap lingkungan, seperti pembuatan Instalasi Pengolahan Limbah (IPAL) yang memadai atau menggunakan kembali limbah cair tahu untuk berbagai keperluan.
\end{abstract}

Kata kunci: Persepsi Masyarakat, Limbah Tahu, Tahu, Limbah, Sungai

https://doi.org/10.37598/tameh.v10i2.153 


\section{Pendahuluan}

Tahu merupakan makanan kaya protein yang berbahan dasar kacang kedelai. Kandungan protein, kalsium serta nutrisi penting lainnya yang dikandung oleh tahu membuatnya digemari oleh semua orang, tidak terkecuali di Indonesia. Tahu sering kali digunakan dalam berbagai olahan makanan di Indonesia, termasuk diolah menjadi air tahu atau yang biasa disebut dengan susu kedelai.

Industri tahu adalah salah satu industri rumah tangga yang termasuk dalam kategori industri kecil. Pada umumnya industri kecil seperti industri tahu hanya memiliki peralatan dan sistem pengolahan yang sederhana. Dari segi lingkungan, berkembangnya industri rumah tangga cukup membahayakan bagi kesehatan karena tidak menghiraukan tata letak pabrik maupun sistem pembuangan limbah. Hal ini mengakibatkan banyak lingkungan di sekitar pabrik mulai tercemar, baik skala kecil maupun besar [1]. Kepala Badan Lingkungan Hidup Jawa Timur turut menyatakan bahwa mayoritas industri skala kecil dan menengah tidak memiliki Instalasi Pengolahan Limbah (IPAL) yang memadai, sehingga limbah hasil usaha umumnya langsung dibuang ke sungai [2]. Padahal tersedianya IPAL merupakan syarat mutlak yang harus dimiliki semua industri tahu untuk menjamin agar ekosistem dan kelestarian sungai tidak terganggu [3].

Pembuangan limbah cair ke sungai tanpa pengolahan memiliki dampak buruk terhadap lingkungan. Sungai sebagai salah satu tempat yang umum digunakan sebagai lahan pembuangan limbah tahu oleh para pelaku industri pengolahan tahu. Limbah tahu tidak memenuhi baku mutu air limbah yang diizinkan untuk langsung dibuang ke sungai serta dapat merusak kualitas air sungai. Ditinjau dari parameter pencemaran fisik dan kimia, air sungai yang tercampur dengan air limbah industri tahu juga sudah termasuk dalam kategori tercemar [4]. Air sungai diketahui memiliki rasa masam, berbau serta memiliki $\mathrm{pH}$ 4. Air bersih menurut syarat baku mutu adalah air yang tidak berasa dan tidak berbau, serta memiliki pH berkisar 6,5 - 8,5 menurut Permenkes No 492 Tahun 2010 [5], 5 - 9 menurut PP No 82/200 [6] dan 7 - 8 menurut Permenkes No 32 Tahun 2017 [7].

Pembuangan limbah tahu juga berpengaruh terhadap estetika sungai yaitu merubah warna air sungai menjadi putih [8]. Limbah tahu juga menyebabkan timbulnya bau tidak sedap dan eutrofikasi atau munculnya nutrien yang berlebihan di sungai [9].

Pembuangan limbah tahu tidak hanya memiliki efek negatif terhadap sungai tetapi juga berpotensi mencemari lahan pertanian hingga air tanah, seperti yang terjadi di Kabupaten Jombang Jawa Timur [10]. Masyarakat di Kabupaten Jombang tidak bisa menggunakan air permukaan lagi dikarenakan telah tercemar oleh limbah tahu. Limbah tahu dari 71 industri tahu di daerah tersebut dikonfirmasi membuang limbah tanpa pengolahan ke lingkungan sekitar hingga mencemari kanal sekunder Rejoagung II.

Menurut Bappeda, industri pengolahan tahu dan tempe berpotensi mencemari sungai di Kota Banda Aceh, dikarenakan beberapa pelaku usaha industri membuang limbah cair hasil industri ke badan sungai tanpa pengolahan terlebih dahulu. Disebutkan, terdapat 3 (tiga) industri tahu di kawasan sungai Krueng Daroy dan Krueng Doy yang termasuk dalam kategori ini [11]. Berdasarkan hal tersebut, penelitian ini dibuat untuk mengetahui persepsi masyarakat terhadap dampak limbah tahu di sekitar sungai.

Penelitian ini bertujuan untuk mengetahui persepsi masyarakat terhadap dampak limbah tahu di lingkungan sekitar dengan studi kasus sungai Krueng Daroy dan Krueng Doy serta mengevaluasi pemahaman masyarakat dalam hal dampak limbah tahu terhadap lingkungan. Penelitian ini dilakukan dengan menggunakan metode kualitatif. Data-data diperoleh melalui kuesioner, observasi serta wawancara. Data yang diperoleh kemudian diolah secara deskriptif dan pembobotan. Hasil penelitian disajikan dalam tiga kategori, yaitu persepsi masyarakat terhadap estetika, persepsi masyarakat terhadap bau, dan persepsi masyarakat terhadap dampak limbah tahu pada lingkungan. 


\section{Tinjauan Pustaka}

\subsection{Sungai}

Air adalah kebutuhan yang sangat esensial bagi kehidupan manusia. Air merupakan senyawa kimia yang fungsinya tidak dapat digantikan oleh senyawa lainnya [12]. Sungai sebagai salah satu sumber air harus dijaga kesehatannya. Saat ini, kondisi sungai-sungai di Indonesia sangat memprihatinkan. Direktur Forest and Freshwater dari World Wide Fund for Nature (WWF) Indonesia pada Hari Air Dunia Tahun 2019 menyatakan bahwa 82\% dari 550 sungai di Indonesia dalam keadaan tercemar [13]. Sungai-sungai ini sebagian besar tercemar karena limbah domestik atau limbah industri [14].

Peningkatan jumlah penduduk yang signifikan menyebabkan bertambahnya kebutuhan akan pemanfaatan sumber daya air. Di lain pihak, sumber daya air yang layak digunakan semakin sulit untuk ditemukan dikarenakan penururan kualitas air akibat pencemaran. Penurunan kualitas air meningkatkan potensi bahaya bagi makhluk hidup pengguna sumber daya air tersebut [15].

Pencemaran sungai telah terjadi dalam jangka waktu yang lama dan telah berdampak terhadap lingkungan. Pencemaran sungai di Indonesia umumnya terjadi karena pembuangan limbah industri, limbah domestik, serta limbah pertanian [16]. Dampak pencemaran ini berupa penurunan kualitas lingkungan yang diakibatkan oleh pembuangan limbah ke sungai tanpa pengolahan yang tepat [17].

\subsection{Limbah}

Limbah adalah ampas suatu kegiatan yang memiliki kandungan berbahaya yang baik karena sifat maupun jumlahnya dapat membahayakan lingkungan serta makhluk hidup lainnya [18]. Limbah yang dihasilkan dari suatu kegiatan dapat berbentuk padat, cair, gas, dan suara. Limbah cair terbagi limbah cair terbagi menjadi limbah cair domestic (domestic wastewater), limbah cair industri (industrial wastewater), rembesan dan luapan (infiltration and inflow), serta air hujan (storm water) [19]. Limbah cair dapat pula diklasifikasikan menjadi feses dan urun (human excreta), air limbah (sewage), dan hasil buangan industri (industrial waste) [20].

\subsection{Limbah Tahu}

Limbah yang diperoleh dari industri tahu terbagi menjadi dua bentuk, yaitu limbah padat dan limbah cair. Limbah padat dari industri tahu biasanya dimanfaatkan sebagai pakan ternak, sedangkan limbah cair seringkali tidak mengalami pengolahan yang memadai. Pembuangan limbah tanpa pengolahan ke sungai memberikan dampak negatif terhadap sungai. Pabrik tahu yang membuang limbahnya ke sungai dapat mencemari air sungai dan mengganggu ekosistem air sungai. Selain itu, limbah cair tahu memiliki kandungan protein tinggi yang dapat menyebabkan protein terurai dan menimbulkan bau busuk [21].

Pembuangan limbah tahu juga mengakibatkan kerusakan lingkungan yang mengganggu ekosistem serta membahayakan kesehatan manusia [22]. Industri tahu juga menyebabkan penurunan kualitas air yang menyebabkan berkurangnya spesies ikan di perairan sekitar pabrik [23]. Oleh sebab itu, pengelolaan limbah tahu ini merupakan hal yang sangat krusial.

Limbah tahu sudah seharusnya diolah sebelum dibuang ke badan air. Selain pengolahan dengan menggunakan IPAL, alternatif pengelolaan limbah cair dapat pula dilakukan melalui upaya penggunaan limbah cair sebagai pupuk organik. Pada penelitian dengan menggunakan sawi putih, limbah tahu yang digunakan sebagai pupuk cair organik terbukti mampu meningkatkan pertumbuhan dan hasil tanaman [24]. Limbah tahu juga terbukti meningkatkan pertumbuhan dan produksi kangkung darat [25]. Limbah tahu dapat pula dimanfaatkan sebagai limbah organik untuk berbagai tumbuhan herba, perdu dan pohon [26].

\subsection{Penelitian Terdahulu}

Beberapa penelitian dilakukan pada sungai Krueng Daroy dan Krueng Doy terkait pencemaran air sungai. Dari penelitian [27] diketahui berdasarkan populasi plankton yang hidup di sungai Krueng Daroy Banda Aceh dapat disimpulkan bahwa sungai ini tercemar sedang dan kurang kondusif untuk pertumbuhan plankton dikarenakan aktivitas 
manusia yang mempengaruhi kualitas air di sekitarnya. Aktivitas serta perilaku masyarakat memegang peranan penting dalam menjaga kualitas air. Perilaku yang kurang baik memberikan efek buruk terhadap kualitas air Berdasarkan hasil penelitian [28], kualitas air di Sungai Kr. Daroy dan Kr. Doy termasuk dalam kategori kurang baik. Penelitian lainnya [29] menyatakan bahwa kualitas air di bagian hulu sungai Krueng Daroy memenuhi standar Kemenkes, sedangkan bagian hilir hingga muara telah terindikasi tercemar, umumnya karena limbah rumah tangga, drainase, limbah pasar, limbah pabrik tahu, dan sebagainya yang terletak di sepanjang aliran sungai Krueng Daroy.

\section{Metode Penelitian}

Penelitian ini dilakukan pada 2 lokasi sungai yaitu Sungai Krueng Daroy dan Sungai Krueng Doy (Gambar 1 dan Gambar 2). Lokasi penelitian dibatasi sepanjang $500 \mathrm{~m}$ ke arah hilir dari lokasi pabrik tahu. Perhitungan dilakukan hanya pada wilayah kawasan aliran sungai Kr. Daroy di Gampong Geuceu Kayee Jato Kecamatan Banda Raya dan kawasan aliran sungai $\mathrm{Kr}$. Doy di Lamtemen Timur Kecamatan Jaya Baru, Kota Banda Aceh.

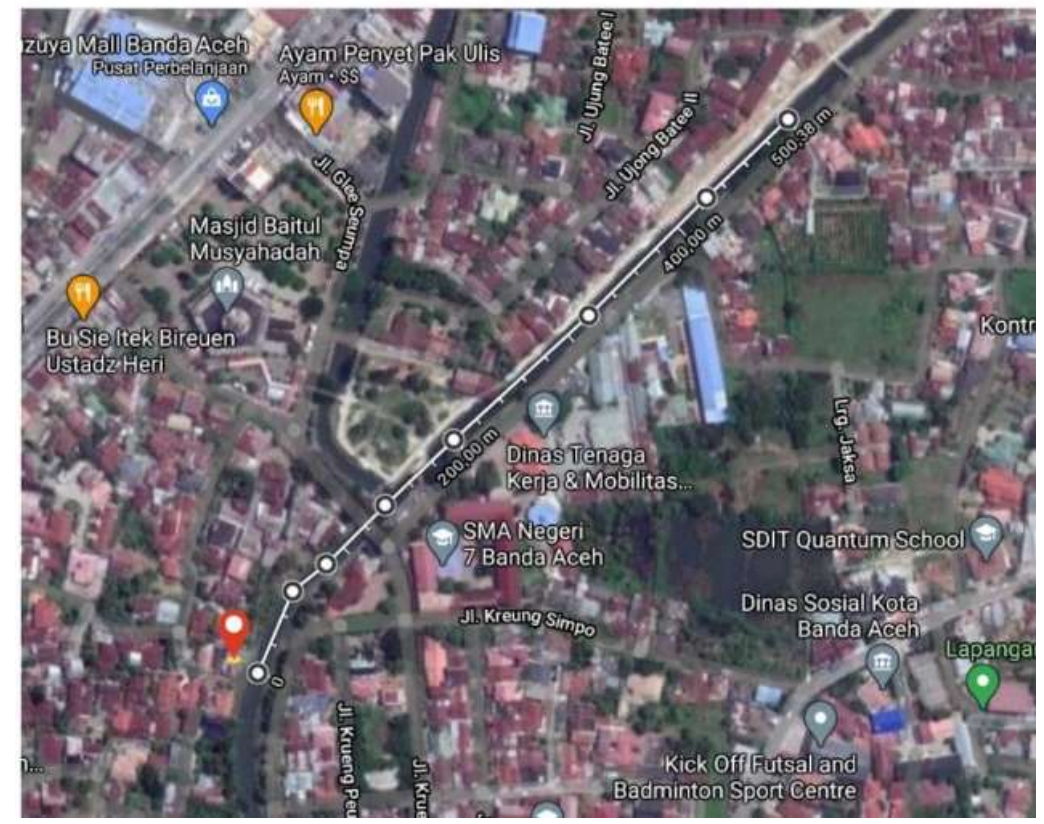

Gambar 1. Lokasi Penelitian (Kr. Daroy)

\subsection{Teknik Pengumpulan Data}

Pengumpulan data dilakukan melalui observasi lapangan pada lokasi penelitian dan dengan menggunakan kuesioner, observasi serta wawancara. Kuesioner disebarkan kepada masyarakat yang tinggal di sekitar Sungai Krueng Daroy dan Sungai Krueng Doy serta masyarakat yang beraktivitas di sekitar kawasan tersebut. Pengumpulan data dilakukan dengan menggunakan kuesioner skala Likert, sedangkan wawancara dan observasi dilakukan dengan secara langsung di daerah lokasi penelitian.
Penentuan sampel dilakukan dengan menggunakan metode random sampling. Jumlah sampel yang digunakan dalam penelitian ini berjumlah 200 orang yang terdiri dari $60 \%$ penduduk sekitar lokasi penelitian dan $40 \%$ adalah pengguna jalan serta masyarakat yang bekerja atau beraktivitas di sekitar lokasi penelitian. 


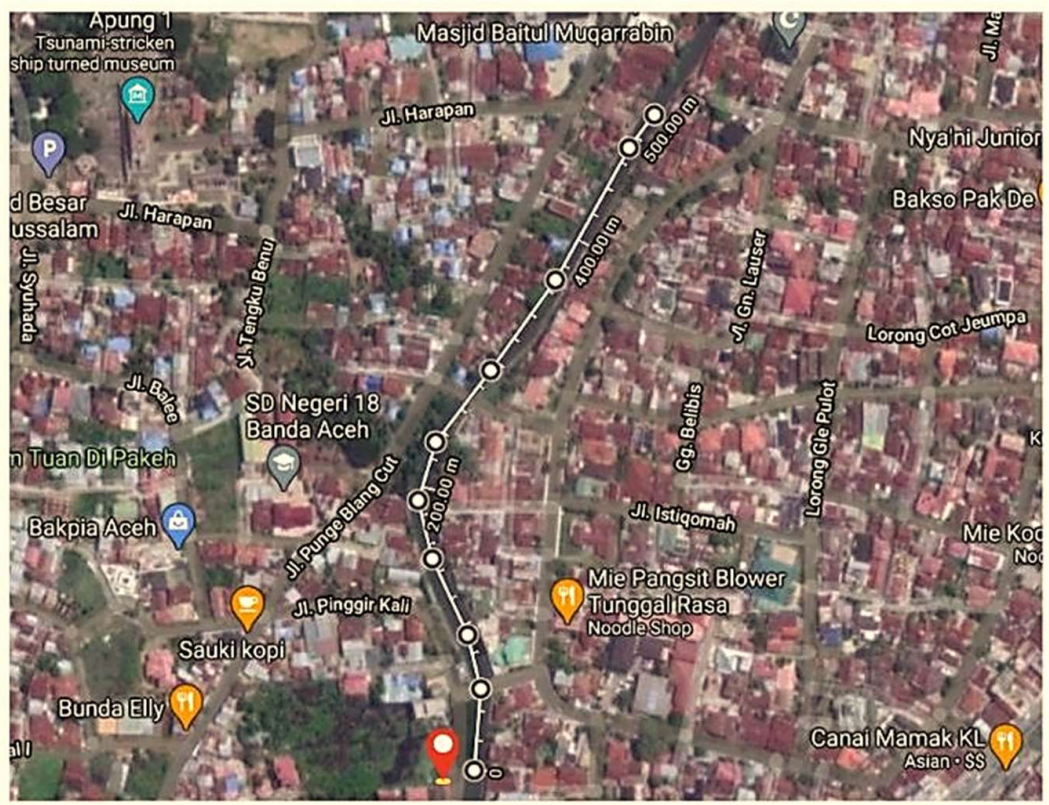

Gambar 2. Lokasi Penelitian (Kr. Doy)

\subsection{Teknik Analisis Data}

Analisis data pada penelitian ini menggunakan teknik analisis deskriptif dan pembobotan. Analisis deskriptif digunakan untuk menilai skala sikap yang diperoleh dari data kuesioner Skala Likert yang menyatakan 5 tingkatan jawaban pernyataan sikap berupa sikap sangat setuju (SS), setuju (S), cukup setuju (CS), kurang setuju (KS), dan tidak setuju (TS). Analisis dilanjutkan dengan pembobotan (skoring) dan rentang kategori.

Data kualitatif yang diperoleh dari kuesioner akan diubah menjadi nilai skor menggunakan persamaan 1 [30]

$P=\frac{x}{x_{i}} \times 100 \%$

Keterangan:

$\mathrm{P}$ = persentase;

$X=$ nilai jawaban responden pada satu item;

$x_{i}=$ nilai ideal.

Dalam penelitian ini, bobot nilai untuk kategori $S S=5, S=4, C S=3, K S=2$, dan $T S=1$. Jawaban dari kuesioner yang berupa skoring ini akan diolah kembali untuk menilai tingkat persepsi masyarakat terhadap dampak limbah tahu pada lingkungan. Perhitungan rentang skala untuk menentukan kriteria tiap indikator adalah sebagai berikut [31].

1. Menentukan rentang skor tertinggi dan terendah dengan mengalikan bobot nilai terendah dan tertinggi dengan jumlah responden;
$\mathrm{n} \quad=1 \times 200=200$
$\mathrm{m}=5 \times 200=1000$

2. Menentukan rentang skala (RS) dengan persamaan (2).

$R S=\frac{(m-n)}{b}$

\section{Keterangan:}

$\mathrm{RS}$ = rentang skor;

$\mathrm{m}$ = skor tertinggi item;

$\mathrm{n}=$ skor terendah item;

b = jumlah kelas.

Dengan menggunakan persamaan (2), rentang skor kemudian diaplikasikan untuk menginterpretasi skor penilaian. Interpretasi 
skor digunakan untuk menginterpretasi hasil jawaban dari kuesioner. Persepsi masyarakat diinterpretasikan dengan 5 kriteria seperti yang disajikan pada Tabel 1

Tabel 1. Interpretasi Skor

\begin{tabular}{cc}
\hline Hasil & Kriteria \\
\hline $200-359$ & Tidak mengganggu \\
$360-519$ & Cukup Mengganggu \\
$520-679$ & Agak mengganggu \\
$680-839$ & Mengganggu \\
$840-1000$ & Sangat mengganggu \\
\hline
\end{tabular}

\section{Hasil dan Pembahasan}

Setelah melalui tahapan penyebaran kuesioner, wawancara serta observasi langsung di lapangan, data-data yang ada kemudia diolah untuk mendapatkan hasil berupa tingkat persepsi masyarakat.

\subsection{Identitas Responden}

Penelitian ini menggunakan responden sebanyak 200 orang yang kesemuanya berada dalam usia produktif. Mayoritas responden adalah usia 15 - 25 tahun dengan persentase $55 \%$, diikuti dengan usia di atas 35 tahun sebanyak 25,5\% dan usia 25 - $35 \%$ dengan persentase sebesar 19,5\% (Tabel 2).

Tabel 2. Klasifikasi Umur Responden

\begin{tabular}{ccc}
\hline Umur & Frekuensi & Persentase \\
\hline $15-25$ Tahun & 110 & 55 \\
$25-35$ tahun & 39 & 19.5 \\
$>35$ tahun & 51 & 25.5 \\
\hline Total & 200 & 100 \\
\hline
\end{tabular}

Ditinjau dari segi pendidikan, mayoritas responden yang berhasil ditemui pada penelitian ini berpendidikan SMA dengan persentase sebesar $56 \%$ dan lulusan S1 dengan persentase sebesar $35 \%$ (Tabel 3 ). Mayoritas responden berprofesi sebagai pelajar atau mahasiswa.
Tabel 3. Klasifikasi Pendidikan Responden

\begin{tabular}{ccc}
\hline Pendidikan & Frekuensi & Persentase \\
\hline SD & 1 & 0.5 \\
SMP & 1 & 0.5 \\
SMA & 112 & 56 \\
S1 & 70 & 35 \\
Lainnya & 16 & 8 \\
\hline Total & 200 & 100 \\
\hline
\end{tabular}

\subsection{Persepsi Masyarakat terhadap Estetika}

Mayoritas responden pada penelitian ini merupakan masyarakat pengguna kawasan sekitar Sungai Kr. Daroy dan Kr. Doy, terutama penduduk di sekitar lokasi pabrik tahu yang mengalirkan limbah ke sungai tersebut. Persepsi terhadap estetika yang muncul berupa tanggapan dan penilaian yang didasarkan pada pengalaman pribadi responden selama melintasi dan tinggal di lokasi penelitian.

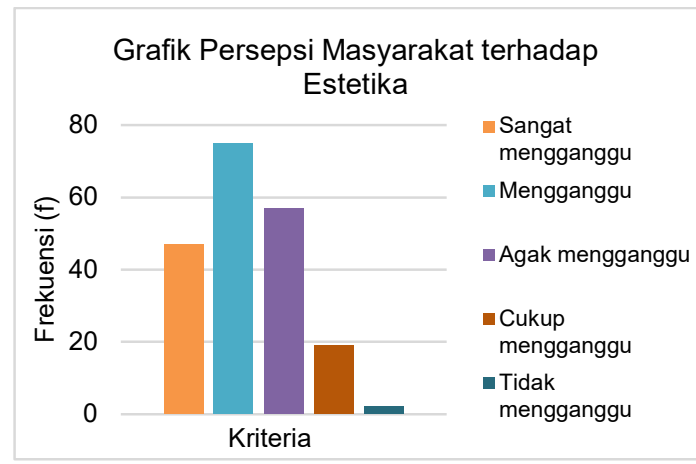

Gambar 3. Persepsi Masyarakat terhadap Estetika

Dari Gambar 3 terlihat persepsi masyarakat terhadap estetika akibat adanya limbah tahu yang dibuang ke sungai. Terdapat 47 responden yang merasa limbah tahu yang dibuang ke sungai sangat mengganggu estetika, 75 responden beranggapan mengganggu dan 57 responden beranggapan agak mengganggu. Hanya 2 responden yang beranggapan bahwa limbah tahu tidak memiliki dampak terhadap estetika sungai dan di sekitarnya. Hal ini menunjukkan bahwa mayoritas responden berpendapat bahwa limbah tahu memiliki dampak negatif terhadap estetika sungai dan kawasan sekitarnya. Limbah tahu yang dibuang ke sungai tanpa penanganan terlebih dahulu menyebabkan air 
sungai berubah warna dan mengakibatkan lingkungan menjadi terlihat kumuh dan kotor.

Tabel 4 menunjukkan tingkat persepsi masyarakat terhadap estetika akibat adanya limbah tahu yang dibuang ke sungai. Berdasarkan Tabel 4, hanya 0,3\% responden yang merasa limbah tahu tidak mengganggu estetika, sedangkan sisanya 99,7\% merasa bahwa limbah tahu yang dibuang ke sungai mengganggu estetika di lingkungan sekitarnya, baik yang termasuk dalam kriteria sangat mengganggu, mengganggu, agak mengganggu, hingga cukup mengganggu estetika.

Tabel 4. Tingkat Persepsi Masyarakat Terhadap Estetika

\begin{tabular}{cccccc}
\hline No & Kriteria & Frekuensi & Bobot Nilai & Jumlah & Persentase \\
\hline 1 & Sangat mengganggu & 47 & 5 & 235 & 31,5 \\
2 & Mengganggu & 75 & 4 & 300 & 40,2 \\
3 & Agak mengganggu & 57 & 3 & 171 & 22,9 \\
4 & Cukup mengganggu & 19 & 2 & 38 & 5,1 \\
5 & Tidak mengganggu & 2 & 1 & 2 & 0,3 \\
\hline
\end{tabular}

\subsection{Persepsi Masyarakat terhadap Bau}

Gambar 4 memperlihatkan persepsi masyarakat terhadap bau yang ditimbulkan oleh limbah tahu yang dibuang ke sungai. Terdapat 76 responden yang merasa bau yang ditimbulkan oleh limbah tahu yang dibuang ke sungai sangat mengganggu, 80 responden beranggapan mengganggu dan 36 responden beranggapan agak mengganggu. Hanya 5 dari 200 responden orang yang beranggapan bahwa limbah tahu tidak menyebabkan bau terhadap lingkungan di sekitar sungai. Berdasarkan Gambar 4, mayoritas responden berpendapat bahwa limbah tahu memiliki dampak negatif dalam hal menyebabkan bau tidak sedap terhadap sungai dan kawasan sekitarnya.

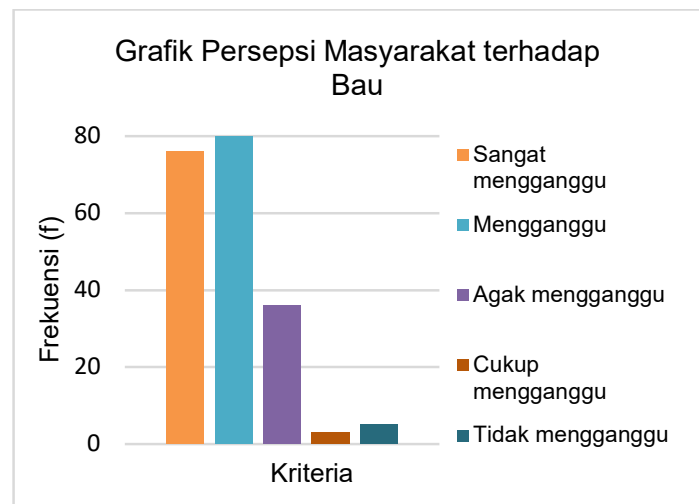

Gambar 4. Persepsi Masyarakat terhadap Bau

Tabel 5. Tingkat Persepsi Masyarakat Terhadap Bau

\begin{tabular}{cccccc}
\hline No & Kriteria & Frekuensi & Bobot Nilai & Skor & Persentase \\
\hline 1 & Sangat mengganggu & 76 & 5 & 380 & 46,4 \\
2 & Mengganggu & 80 & 4 & 320 & 39,1 \\
3 & Agak mengganggu & 36 & 3 & 108 & 13,2 \\
4 & Cukup mengganggu & 3 & 2 & 6 & 0,7 \\
5 & Tidak mengganggu & 5 & 1 & 5 & 0,6 \\
\hline
\end{tabular}


Tingkat persepsi masyarakat terhadap bau ditunjukkan dalam Tabel 5. 99,4 \% responden setuju bahwa bau yang mucul akibat adanya limbah tahu mengganggu lingkungan sekitar, baik yang termasuk dalam kriteria sangat mengganggu, mengganggu, agak mengganggu, hingga cukup mengganggu estetika.

Tabel 6. Tingkat Persepsi Masyarakat Terhadap Dampak Limbah Tahu pada Lingkungan

\begin{tabular}{|c|c|c|c|c|c|c|c|}
\hline \multirow{2}{*}{ Indikator } & \multicolumn{5}{|c|}{ Sikap } & \multirow{2}{*}{ Skor } & \multirow{2}{*}{ Kriteria } \\
\hline & SS & $\mathrm{S}$ & CS & $\mathrm{KS}$ & TS & & \\
\hline $\begin{array}{l}\text { Limbah cair tahu yang dibuang ke } \\
\text { sungai menyebabkan sungai tercemar }\end{array}$ & 101 & 56 & 37 & 6 & 0 & 852 & $\begin{array}{c}\text { Sangat } \\
\text { Mengganggu }\end{array}$ \\
\hline $\begin{array}{l}\text { Limbah cair tahu membuat lingkungan } \\
\text { sekitar terlihat kotor }\end{array}$ & 47 & 75 & 57 & 19 & 2 & 746 & Mengganggu \\
\hline $\begin{array}{l}\text { Limbah cair tahu menyebabkan bau } \\
\text { tidak sedap }\end{array}$ & 76 & 80 & 36 & 3 & 5 & 819 & Mengganggu \\
\hline $\begin{array}{l}\text { Limbah cair tahu menyebabkan warna } \\
\text { air sungai berubah }\end{array}$ & 74 & 61 & 13 & 26 & 26 & 731 & Mengganggu \\
\hline $\begin{array}{l}\text { Limbah cair tahu menyebabkan } \\
\text { terganggunya ekosistem sungai }\end{array}$ & 75 & 58 & 43 & 20 & 4 & 780 & Mengganggu \\
\hline Total skor & \multicolumn{7}{|c|}{3928} \\
\hline Rata-rata & \multicolumn{7}{|c|}{785,6} \\
\hline Persentase (\%) & \multicolumn{7}{|c|}{78,56} \\
\hline
\end{tabular}

Total skor tingkat persepsi masyarakat diperoleh sebesar 3928 dari total skor yang diharapkan. Tingkat persepsi masyarakat mencapai $78,56 \%$, artinya lebih dari $75 \%$ responden setuju bahwa limbah tahu memiliki dampak terhadap lingkungan. Dilihat dari ratarata nilai sikap yaitu sebesar 785,6 , sesuai dengan interpretasi skor pada Tabel 1, termasuk dalam kriteria "mengganggu".

Hasil survey lapangan menunjukkan sungai Krueng Daroy dan Krueng Doy terlihat kotor dan berbau. Air sungai di sekitaran Krueng Daroy terlihat lebih bersih dibandingkan dengan air pada Sungai Krueng Doy. Pada sungai Krueng Doy, air terlihat berwarna hijau hingga hitam, yang menandakan bahwa air sungai tidak dalam kondisi baik. Adanya limbah, baik berupa limbah industri maupun limbah rumah tangga mempengaruhi kualitas dari air yang terdapat di sungai. Perubahan warna dan timbulnya bau merupakan indikator pencemaran air.

Berdasarkan hasil wawancara, mayoritas masyarakat paham dan mengerti tentang arti

\subsection{Tingkat Persepsi Masyarakat terhadap} Dampak Limbah Tahu pada Lingkungan

Hasil pengolahan data persepsi masyarakat terhadap dampak limbah tahu terhadap lingkungan disajikan dalam Tabel 6. 
Instalasi Pengolahan Limbah (IPAL) yang memadai atau menggunakan kembali limbah cair tahu untuk berbagai keperluan, salah satunya dengan menjadikan limbah tahu sebagai pupuk cair organik.

\section{Kesimpulan}

Lebih dari $90 \%$ responden setuju bahwa limbah tahu memiliki dampak negatif terhadap estetika lingkungan dan menimbulkan bau yang sangat mengganggu. Tingkat persepsi masyarakat terhadap limbah tahu pada lingkungan sungai diperoleh $78,56 \%$, artinya lebih dari $75 \%$ responden setuju bahwa limbah tahu memiliki dampak terhadap lingkungan. Dilihat dari ratarata nilai sikap yaitu sebesar 785,6 termasuk dalam kriteria "mengganggu". Hal ini menunjukkan bahwa limbah tahu memiliki dampak negatif terhadap lingkungan. Masih terdapat masyarakat serta pelaku usaha yang minim pemahaman akan dampak limbah tahu terhadap lingkungan. Oleh karena itu, perlu adanya peningkatan pemahaman pelaku usaha akan dampak limbah tahu terhadap lingkungan beserta beserta langkah-langkah yang harus dilakukan untuk meminimalisasi dampaknya terhadap lingkungan, seperti pembuatan Instalasi Pengolahan Limbah (IPAL) yang memadai atau menggunakan kembali limbah cair tahu untuk berbagai keperluan.

\subsection{Saran}

Para pelaku usaha diharapkan lebih meningkatkan atensi terhadap lingkungan sekitar dan melakukan upaya-upaya untuk mengurangi dampak limbah tahu terhadap sungai. Pemerintah juga perlu memberikan sosialisasi lebih lanjut kepada para pelaku usaha terkait pengolahan limbah beserta aturan-aturan pembuangan limbah ke sungai. Dengan demikian, diharapkan pemahaman para pelaku usaha akan dampak limbah tahu terhadap lingkungan akan semakin meningkat.

\section{Daftar Pustaka}

[1] Sayow, Febrian, dkk., 2020. Analisis Kandungan Limbah Industri Tahu dan
Tempe Rahayu di Kelurahan Uner Kecamatan Kawangkoan Kabupaten Minahasa. Agri-sosio Ekonomi Unsrat, 16 (2), pp. 245-252.

[2] KBR, 2018. Ribuan Industri Kecil \& Menengah Tak Dilengkapi Instalasi Pengolahan Limbah yang Memadai. [Online] (Updated 12 Juli 2018).

[3] Halo Semarang, 2019. Minimnya Pemahaman Pengolahan Limbah pada Pabrik Tahu Berpotensi Cemari Lingkungan. [Online] (Updated 09 Desember 2019).

[4] Sarofah, A. K., 2021. Pengaruh Limbah Tahu terhadap Kualitas Air Sungai di Desa Mejing Kecamatan Candimulyo. Indonesian Journal of Nature Science Education (IJNSE), 4 (1), pp. 400-403.

[5] Peraturan Menteri Kesehatan No. 492/ MENKES/ PER/ IV/ 2010 tentang Persyaratan Kualitas Air Minum.

[6] Peraturan Pemerintah Republik Indonesia No 82 Tahun 2001 tentang Pengelolaan Kualitas Air dan Pengendalian Pencemaran Lingkungan.

[7] Peraturan Menteri Kesehatan Republik Indonesia No 32 Tahun 2017 tentang Standar Baku Mutu Kesehatan Lingkungan dan Persyaratan Kesehatan Air untuk Keperluan Higiene Sanitasi, Kolam Renang, Solus per Aqua, dan Pemandian Umum.

[8] Merdeka.com, 2020. Miris, Air Sungai di Jombang Berwarna Putih Diduga Kena Limbah Pabrik Tahu. [Online] (Updated 12 November 2020)

[9] Kompasiana, 2020. Kerusakan Lingkungan Akibat Limbah Tahu. [Online] (Updated 1 Mei 2020)

[10] DetikNews, 2020. Ini Dampak Limbah Home Industri Tahu di Jombang yang Dibuang Sembarangan. [Online] (Updated 25 November 2020).

[11] Badan Perencanaan Pembangunan Daerah Pemerintah Kota Banda Aceh. 2011. Laporan Evaluasi Pelaksanaan 4 Tahun Rencana Pembangunan Jangka Menengah (RPJM) Kota Banda Aceh Tahun 2007-2010. Banda Aceh: Bappeda.

[12] Achmad, R., 2004. Kimia Lingkungan. Edisi I. Yogyakarta: Andi Offset.

[13] Republika, 2019. 82 Persen Sungai di Indonesia Tercemar dan Kritis. [Online] (Updated 23 Maret 2019).

[14] Antaranews, 2014. 70 Persen Sungai Tercemar Limbah Rumah Tangga. [Online] (Updated 27 November 2014).

[15] Effendi, H., 2003. Telaah Kualitas Air bagi Pengelolaan Sumber Daya dan Lingkungan Perairan. Yogyakarta: Kanisius.

[16] Rismawati, Laila dkk., 2020. Kajian Persepsi dan Perilaku Masyarakat terhadap Pencemaran Air Sungai Martapura. EnviroScienteae,16 (3), pp. 389-396. 
[17] Suriawiria, U., 2003. Air dalam Kehidupan dan Lingkungan yang Sehat. Bandung: Penerbit Alumni.

[18] Mahida, UN., 1984. Pencemaran Air dan Pemanfaatan Limbah Industri. Jakarta: Rajawali.

[19] Suharto., 2011. Limbah Kimia dalam Pencemaran Udara dan Air. Yogyakarta: Andi Offset.

[20] Chandra, B., 2007. Pengantar Kesehatan Lingkungan. Jakarta: EGC.

[21] Kesuma, DD., Widyastuti, M., 2013. Pengaruh Limbah Industri Tahu Terhadap Kualitas Air Sungai di Kabupaten Klaten. Jurnal Bumi UGM, 2, pp.1-10

[22] Adack, J., 2013. Dampak Pencemaran Limbah Pabrik Tahu terhadap Lingkungan Hidup. Lex Administratum, 1 (3), pp. 78-87.

[23] Robin \& Supendi, A., 2016. Analisis Dampak Limbah Cair Industri Tahu terhadap Penurunan Kualitas Air dan Keragaman Ikan Air Tawar di Sungai Cipelang Kota Sukabumi. Ummi, 10 (2), pp. 52-56.

[24] Marian, E \& Tuhuteru, S., 2019. Pemanfaatan Limbah Cair Tahu sebagai Pupuk Organik Cair pada Pertumbuhan dan Hasil Tanaman Sawi Putih (Brasica pekinensis). Agritop, 17 (2), pp. 135-145.

[25] Aliyenah, Napoleon, A., dan Yudono, B., 2015. Pemanfaatan Limbah Cair Industri Tahu sebagai Pupuk Cair Organik terhadap Pertumbuhan dan Produksi Tanaman Kangkung Darat (Ipomoea Reptans Poir). Jurnal Penelitian Sains, 17 (3), pp. 102110.

[26] Farhana, D. dan Wijaya, Y. R. P, 2021 Pemanfaatan Limbah Cair Tahu sebagai Pupuk Organik Cair untuk Berbagai Tanaman di Kampung Lengkong, Kota Langsa. Prosiding SemNas Peningkatan Mutu Pendidikan, 2 (1), pp. 83-87

[27] Zai, AP dkk., 2019. Penetapan Kualitas Air berdasarkan Keanekaragaman Plankton di Krueng Daroy Provinsi Aceh. Jurnal Biologi Edukasi 23, 11(2), pp. 34-38.

[28] Shaskia, N. dan Yunita, I., 2021. Evaluasi Perilaku Masyarakat Terhadap Kualitas Air pada Sungai Krueng Daroy dan Krueng Doy. VOCATECH: Vocational Education and Technology Journal, 2(2), pp. 88-94.

[29] Mulyani, Marwan dan Ismail, N., 2012. River Water Quality Spatial Analysis Based on Physical Parameter Throughout Krueng Daroy In Banda Aceh. Journal of Aceh Physics Society, SS, 1 (1), pp. 1-2.

[30] Sugiyono., 2014. Metode Penelitian Pendidikan Pendekatan Kuantitatif, Kualitatif, dan R\&D. Bandung: Alfabeta.

[31] Umar, H., 1999. Metodologi Penelitian, Aplikasi dalam Pemasaran. Jakarta: PT. Gramedia Pustaka Utama. 